\title{
Research on the Reform of Accounting Education Based on the Perspective of the Differences between Professional Ability Supply and Demand
}

\author{
Peng Sun \\ College of Economics and Management \\ Qilu Normal University \\ Jinan, China
}

\author{
Weishuang $\mathrm{Xu}$ \\ College of Economics and Management \\ Qilu Normal University \\ Jinan, China
}

\begin{abstract}
The more developed the economy, the more important the accounting" has been confirmed by accounting theory and practice circles, and the competition of accounting professional ability has become an important part of the competition of world's comprehensive national strength. But in recent years, the contradiction between supply and demand in China's accounting market has the tendency of further expansion. The discrepancy between supply and demand of accounting professional ability is the root cause of the contradiction of China's accounting market. Based on this, this paper intends to analyze the current situation of supply and demand of accounting professional ability and the reasons for the differences. And based on the perspective of narrowing the gap between supply and demand of accounting professional ability, this paper intends to discuss the coping strategies of China's accounting education reform from the aspects of constructing talents training mode for professional ability training and the active participation of relevant stakeholders.
\end{abstract}

Keywords-professional ability; contradiction between supply and demand; accounting education

\section{INTRODUCTION}

"The more developed the economy, the more important the accounting" has been confirmed by accounting theory and practice circles, and the competition of accounting professional ability has become an important part of the competition of world's comprehensive national strength.

\begin{abstract}
According to the information provided by Accounting Qualification Evaluation Center of the Ministry of Finance(2016) [1], the supply of accounting practitioners in our country continues to increase, and the educational structure, age structure and regional distribution structure of accounting practitioners are also continuously optimized in recent years. At the same time, as shown in Figure 1, the effective supply of accounting staff in our country during 2011-2013 is still positive, but the effective supply of accounting staff during 2014-2015is negative. This indicates that the contradiction between supply and demand of accountants is expanding gradually. As for the reason, Zhang Jing and Xing Weiquan (2014) [2] think it is the direct result of accounting environment changes, accounting functions expansion and accounting business extension which results in the new changes on accounting staff demand. But this paper thinks that the discrepancy between supply and demand of accounting professional ability is the root cause of the contradiction of China's accounting market. Based on this, this paper intends to analyze the current situation of supply and demand of accounting professional ability and the reasons for the differences. And based on the perspective of narrowing the gap between supply and demand of accounting professional ability, this paper intends to discuss the coping strategies of China's accounting education reform.
\end{abstract}

Unit: ten thousand

accounting staff supply $\quad$ excess accounting staff

1873

1689

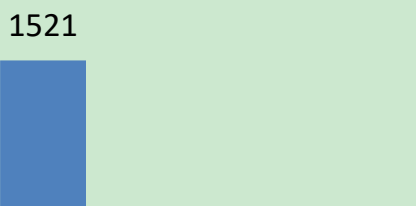

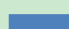

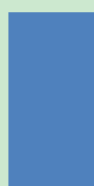

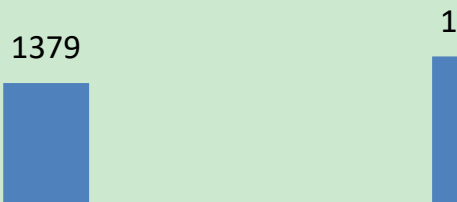

Fig. 1. Accounting staff supply, excess and new added during 2011-2015. 


\section{THE CURRENT SituATION OF SUPPLY AND DEMAND of ACCOUNTING PROFESSIONAL ABILITY}

\section{A. The Current Situation of Accounting Professional Ability Supply}

College training, special training and self-study are three possible ways for the formation of accounting professional ability. Among them, the college training not only plays a key role in the formation of accounting professional ability, but also is the "knocking brick" for accounting staff to engage in related professions. According to the accounting profession rankings during 2016-2017 released by Research Center for China Science Evaluation (RCCSE), there are 467 colleges and universities set up accounting profession at present. If consider other similar profession, such as auditing and financial management etc., it can be said that China's accounting education has developed to a considerable mature stage. But at the same time, most scholars do not have an optimistic attitude towards the current situation of China's accounting education. Luo Wei (2014) [3] thinks that our accounting education emphasizes on factor accounting methods and financial processing knowledge explanations, and often neglects the training of students' professional judgment ability. The manifestation is to overemphasize knowledge and skills, but ignore the content of professional ethics and professional sensitivity etc. Li Mingjuan (2015) [4] think that our country's accounting undergraduate talents training only attaches importance to learning and assessment of knowledge and skills. Graduates generally lack the ability of independent thinking and judgment. Niu Niu (2017) [5] thinks that the importance of knowledge in our accounting education is far more than that of students' own quality. It also ignores the formation and cultivation of students' moral values and values. Hu Huijuan et al. (2017) [6] thinks that accounting education in China's universities pays too much attention to the cultivation of professional ability, but neglects the training of students' innovative and integrated thinking ability and migration ability, and ignores the cultivation of students' practical ability. It can be seen that China's accounting education has overemphasized the cultivation of students' professional knowledge and skills, while ignored the supply of students' comprehensive ability and professional quality.

\section{B. The Current Situation of Accounting Professional Ability Demand}

With the increasing complexity of business environment and the increasing diversity of economic business, the society has created broader and more complex capacity demand for accountants. Whether the graduates have the professional ability required by the demand subject is the premise of they can be reused, and it is also the ultimate basis for testing the quality of accounting undergraduate education. The study conducted by Kavanagh \& Drennan in 2008 [7] found that employers expect accounting graduates have a solid professional basis as well as generic skills such as general business sense, interdisciplinary knowledge to solve complex problems and good interpersonal relations ability. Liu Bin and Han Chuanmo (2013) [8] think that employers are not satisfied with six aspects of accounting graduates' professional, including professional judgment ability, self-learning ability, teamwork ability, prediction and decision-making ability, financial data collection ability and psychological quality. Rao Xi (2017) [9] argues that the demand of society for accounting talent in various sectors, mainly focuses on social responsibility, industry recognition, professional related skills, job-related skills and professional ethics. Luo Wenbing and Wang Juanzhi (2017) [10] thought that enterprises should pay more attention to the self-learning ability, psychological quality and professional judgment ability of accountants. Ma Defu, from Seentao Technology CO.,LTD, also expressed the same view at the Accounting Education Annual Meeting of China Accounting Society in 2013. He believes that the accountants who understand management and with both "science" and "art" ability are in urgent need of the enterprise. It can be seen, unlike accounting education subject which focuses on the supply of knowledge and skills, the main demand subject is more emphasis on the professional ability of accountants, especially the comprehensive professional ability.

\section{Analysis of the Difference between Supply and Demand of Accounting Professional Ability}

There is a great difference between the supply and demand of accounting professional ability in China. If this difference cannot be narrowed promptly and effectively, it will not only hinder the reform of accounting education in China, but also affect the economic development of our country. (1) Affect stakeholder's satisfaction with accounting education and result in the waste of all parties' resources. Luo Wenbing and Wang Juanzhi (2017) think that the overall quality of accounting undergraduate education in China is low. The training programs do not match the needs of professional accountants. There is a big gap between the theoretical training and the professional practice, and the difference between supply and demand of accounting occupational ability. If this situation continues, it means that if the demand subjects want to obtain accounting talents that are used, either to train the recruited personnel, or o recruit people with work experience. If a graduate wants to get a job in the relevant position, it will either rely on self-study, or choose other ways to retrain. In either case, it reflects the dissatisfaction of stakeholders on accounting education and also caused the waste of all parties' resources. (2) Aggravate the structural contradictions between the supply and demand of accounting staff and influence the economic development of our country. The supply of accounting professional ability focuses on the impartment of professional knowledge and skills means that China's accounting education has provided a large number of financial accounting personnel. However, in the process of China's economic transformation and development, financial accounting professionals are facing the situation of elimination. A large number of compound talents, especially the management accounting talents with management decision-making ability and strategic vision are needed by the society. If accounting education fails to provide talents timely according to the needs of economic transformation and development, it will further aggravate the structural contradiction between the supply and demand of 
accounting talents and affect the economic development of our country.

\section{THE REASONS FOR THE CURRENT SituATION OF THE SUPPLY AND DEMAND OF ACCOUNTING PROFESSIONAL} ABILITY

\section{A. The Reform of Accounting Education Does not Cater to the Change of Social Demand Timely}

Although the development of China's accounting education is relatively fast, but in general it is unable to integrate the new requirements of modern society to $t$ accountants timely. The main reason is that our country's accounting education reform is more imitative than innovation. Before the reform of application-oriented transformation, most colleges and university adopted the talents training mode of "academic", namely the training mode of giving priority to professional knowledge imparting. After the reform of application-oriented transformation, a considerable number of colleges and universities have taken "applied" talents training mode. The intention of applicationoriented talents training mode is to train application-oriented talents who can meet the needs of economic and social development, but in fact they embarked on the path of training skilled talents. In fact, no matter what kind of talent training mode, there are very few colleges and universities in innovation and most other colleges and universities can only imitate due to resource and capacity constraints. This leads to the contradiction between simplicity university supply and diversity society demand and thus affects the reform effect of accounting education.

\section{B. Talent Training Mode Is not Conducive to the Cultivation of Students' Comprehensive Professional Ability}

In the higher education reform of mutual imitation, the accounting education lacks the communication with industry circles and accounting profession in the process of definition talent training goals and abilities. Teaching content and teaching methods ignore the ability demand of talent market for accounting graduates and it is difficult to combine accounting and related knowledge to deal with more complex occupation demand. This leads to stakeholders' response on the value of accounting education is ignored (Yang Zheng, Yin Junming, Song Yaqin, 2012) [11]. Undergraduate accounting education in our country generally carries out talents training and teaching mode based on subject supply. In curriculum setting, we emphasize the setting of professional courses around accounting standards. The course name, course content and even the teachers are in the stable state in the long-term (Zhang Xinmin, Zhu Jigao, 2015) [12]. The repetition of some related courses is high and ii does not pay attention to increase the universality of knowledge structure and also ignore the importance of practical teaching. The curriculum on accounting professional ethics and accounting practice is mostly in the form, which fails to enhance the professional moral quality and practical operation ability of accountants. The professional abilities required by accounting profession are not developed consciously in the accounting professional course and there is a big gap between the ability required for career success and those taught in the university classroom (the Institute of Management Accountants, 2016) [13].

\section{The Coping Strategies of ACCOUnting EDUCATION REFORM}

Whether the graduates trained by accounting education can meet the requirements of demand subject on professional capacity is directly related to the role of accounting profession in the development of organization and social economic in the future. It also affects the competitiveness and employment quality of college graduates, affects the attractiveness of accounting profession to young students and ultimately affects the success or failure of accounting education itself. In order to enhance the professional ability of accounting graduates, all colleges and universities need to follow and comply with the requirements of social development, take social needs as their orientation, continuously deepen the reform of talents training mode, and constantly attract the participation of relevant stakeholders during the reform so as to explore the accounting education reform mode adapting to the need of society.

\section{A. Construct a Talents Training Model for Professional Ability Training}

At present, the talents training mode of accounting education has deviated from the training requirements of professional ability. Therefore, it is necessary to construct a talents training mode for professional ability training. (1) Basic ideas. Determine talents training objectives according to the demand of demand subject on professional ability. Revise talent training programs and set reasonable curriculum system and curriculum training objective according to talents training objectives. Equip all necessary teaching resources; improve teaching methods and means according to the curriculum system and curriculum training objectives. Evaluate the effect of talent training according to the requirements of professional ability. Further revise talent training objectives and programs according to the evaluation results and social development needs, so as to build a closed loop talent training mode based on professional ability. (2) Emphasize the central position of students. The main reason for the current situation of academic and applied talents training mode is to neglect students' central position and teachers become the center of talent training. In this case, the theoretical knowledge and operational skills taught by teachers are their own good, but may not be really needed by the demand subject. Therefore, in future education reform, we must take students as the center, take students' needs and society's requirements on professional ability as the starting point, fully respect students' learning autonomy so as to enhance the using efficiency of all parties' resources.

\section{B. Relevant Stakeholders Should Actively Participate in Accounting Education Reform}

Accounting education reform not only needs the innovation of educational thinking and the implementation of these innovations thinking, but also requires a series of 
necessary guarantee conditions. On the one hand, it needs to protect innovators' enthusiasm for innovation and the achievements of innovation. On the other hand, it must also have the function of rectifying so as to reduce the costs associated with innovation. (1) The government should give the necessary support. The government's support is mainly embodied in policy support and top-level design. On the one hand, the government should recognize the necessity of reform and give its support in terms of policies On the other hand, the social status of government determines it can own and dominate more resources and have the opportunity to access the latest achievements of reform frontier. Therefore, the government should make the top-level design so as to provide the necessary guidelines for the smooth progress of reform and avoid further reform to pay more costs. (2) The university should give the necessary support. Various reforms in accounting education will surely touch the existing distribution pattern of interests. While those who adhere to the existing pattern of interests will inevitably set various obstacles for the reform. Based on this, the university can retain the transition period and the trial-and-error period for the reform. During the transition period and trial-anderror period, we should not only let the interests of the stakeholders who are hindering the reform not be damaged, but also let the stakeholders of reform get the corresponding rewards. (3) Social demand subjects give necessary assistance and cooperation. In order to avoid wasting resources in both supply and demand sides, it is hoped that social demand subjects can give necessary assistance in the reform of talents training mode from the following two aspects. One is to provide the necessary base of practice teaching. The second is to give necessary procedural guidance in accounting education reform so as to avoid unnecessary detours in the reform process.

\section{CONCLUSION}

The supply of accounting practitioners in our country continues to increase, and the educational structure, age structure and regional distribution structure of accounting practitioners are also continuously optimized in recent years. accounting education in China's universities pays too much attention to the cultivation of professional ability, but neglects the training of students' innovative and integrated thinking ability and migration ability, and ignores the cultivation of students' practical ability. Although the development of China's accounting education is relatively fast, but in general it is unable to integrate the new requirements of modern society to $t$ accountants timely. The main reason is that our country's accounting education reform is more imitative than innovation. Before the reform of application-oriented transformation, most colleges and university adopted the talents training mode of "academic", namely the training mode of giving priority to professional knowledge imparting. Accounting education reform not only needs the innovation of educational thinking and the implementation of these innovations thinking, but also requires a series of necessary guarantee conditions.

\section{ACKNOWLEDGMENT}

This paper is funded by Key Topics of Qilu Normal University "Ability Model Talents Training Mode Reform of Financial Management Professional" and Shandong Province Undergraduate College Teaching Reform Project "Research on Integrated Path of Vocational Competence, Vocational Qualification and Talent Training Program".

\section{REFERENCES}

[1] http://kuaiji.firstacc.cn/a/20161022/5196.html

[2] Zhang Jing, Xing Weiquan. An Empirical Study on the Gap between Supply and Demand for Accounting Professional Talent Training-Taking Tianjin as an Example[J]. Journal of Higher Education Finance, 2014(09).

[3] Luo Wei. Investigation of Training Accountant Talents at University from the Perspective of Social Demand[J]. Journal of Qujing Normal University, 2014(11).

[4] Li Mingjuan. Research on Accounting Undergraduate Teaching Reform Based on Differences Between Supply and Demand of Professional Ability[J]. Heilongjiang Researches on Higher Education, 2015(10).

[5] Niu Niu. Expert: Accounting Education Should Shorten the Gap between Students' Abilities and Social Needs [N].Accounting Messenger, 2017(09).

[6] Hu Huijuan, Ouyang Yukun, Shen Dong. Analysis on the Ability Expansion of Accounting Professionals Based on Market Demand-an Interpretation of the Perspective of Innovation and Entrepreneurship Education[J]. Human Resource Management, 2017(04).

[7] Kavanagh M. and Drennan L. What Skills and Attributes do an Accounting Graduate Need? Evidence from Student' Perceptions and Employer Expectations [J]. Accounting and Finance, 2008(48).

[8] Liu Bin, Han Chuanmo. the Construction of Accounting Professional Ability Education System under the Model of Intensive Training Personnel[C]. Accounting Education Annual Meeting of China Accounting Society in 2013, 2013(11).

[9] Rao Xi, Luo Yun., Huang Lijia. The Construction of Accounting Personnel Quality Assessment System--Based on the Perspective of Higher Accounting Education Supply Side Reform[J]. Research of Finance and Education, 2017(09).

[10] Luo Wenbing, Wang Juanzhi. Investigation and Analysis on the Satisfaction of Training Quality of Accounting Undergraduate Majors[J]. Theory and Practice of Contemporary Education, 2017(06).

[11] Yang Zheng, Yin Junming, Song Yaqin. The Accounting Professional Skill Need and the Reform of Undergraduate Accounting Education: A Survey Study from the Stakeholders[J]. Accounting Research, 2012(01).

[12] Zhang Xinmin, Zhu Jigao. The Core Curriculum Construction of Undergraduate Accounting Major: Way to Break Through[J]. Accounting Research, 2015(08).

[13] The Institute of Management Accountants. the Future of Accounting Education: Resolving the Crisis of Professional Ability[J]. China Chief Financial Officer, 2016(03). 